\title{
The APSA Congressional Fellowship: A Job With Options
}

\section{Darcia Bowman, Congressional Quarterly Fellow}

An APSA Congressional Fellowsip should not be confused with other internships and fellowships that used to combine career-building experience with low-end salaries-or those in today's world that simply skip the salary. In that context, the APSA program seems almost oldfashioned with its $\$ 35,000$ stipend and its academic approach to opening up the congressional legislative process to journalists, political scientists, and mid-career professionals. The unique opportunities afforded to APSA fellows include time to observe the electoral side of congressional politics in a representative's home district or a senator's state, the opportunity to attend biweekly Wilson Seminars held in collaboration with the Library of Congress and featuring guest speakers like the House parliamentarian and associate Senate historian, a day-long visit to the Maryland State Capitol in Annapolis, and a chance to participate in an exchange program with Canadian parliamentary interns.

Still, as it has since the program's inception in 1953, the "hands-on" experience of working as a congressional staffer remains the heart of the APSA Congressional Fellowship. As the list on the following pages makes clear, Fellows negotiated the substance of their assignments to match their previous professional experience and to enhance their ongoing careers.

If fulfilling the responsibilities of a legislative assistant in a congressional office is the stuff of the dayto-day life of an APSA Congressional Fellow, being selected to spend a week learning about the Canadian Parliament sets the fellowship apart from all the other programs on Capitol Hill.

Like most Americans, my knowledge of Canada came from a few jaunts to Niagara Falls and was supplemented by a few murky details I had picked up in the news about Quebec's attempts to separate from the rest of the country. And this de- spite the fact that I worked within a ten-minute drive from the U.S.-

Canadian border for more than two years as a daily newspaper reporter. As the saying goes, "Americans are benevolently ignorant about Canada, while Canadians are malevolently well-informed about the United States." Being well-aware of this long-standing imbalance of understanding and interest, our gracious Canadian hosts set out to enlighten us.
Over the course of our short stay in Ottawa, Canada's national capital, we heard from a dizzying array of politicians, historians, military leaders, and representatives of federal agencies. We would walk away with nothing short of a comprehensive understanding of the government of our northern neighbors. That this was our hosts' intention was made clear on the cover page of the itinerary the Canadian parliamentary interns prepared for us: "As you are

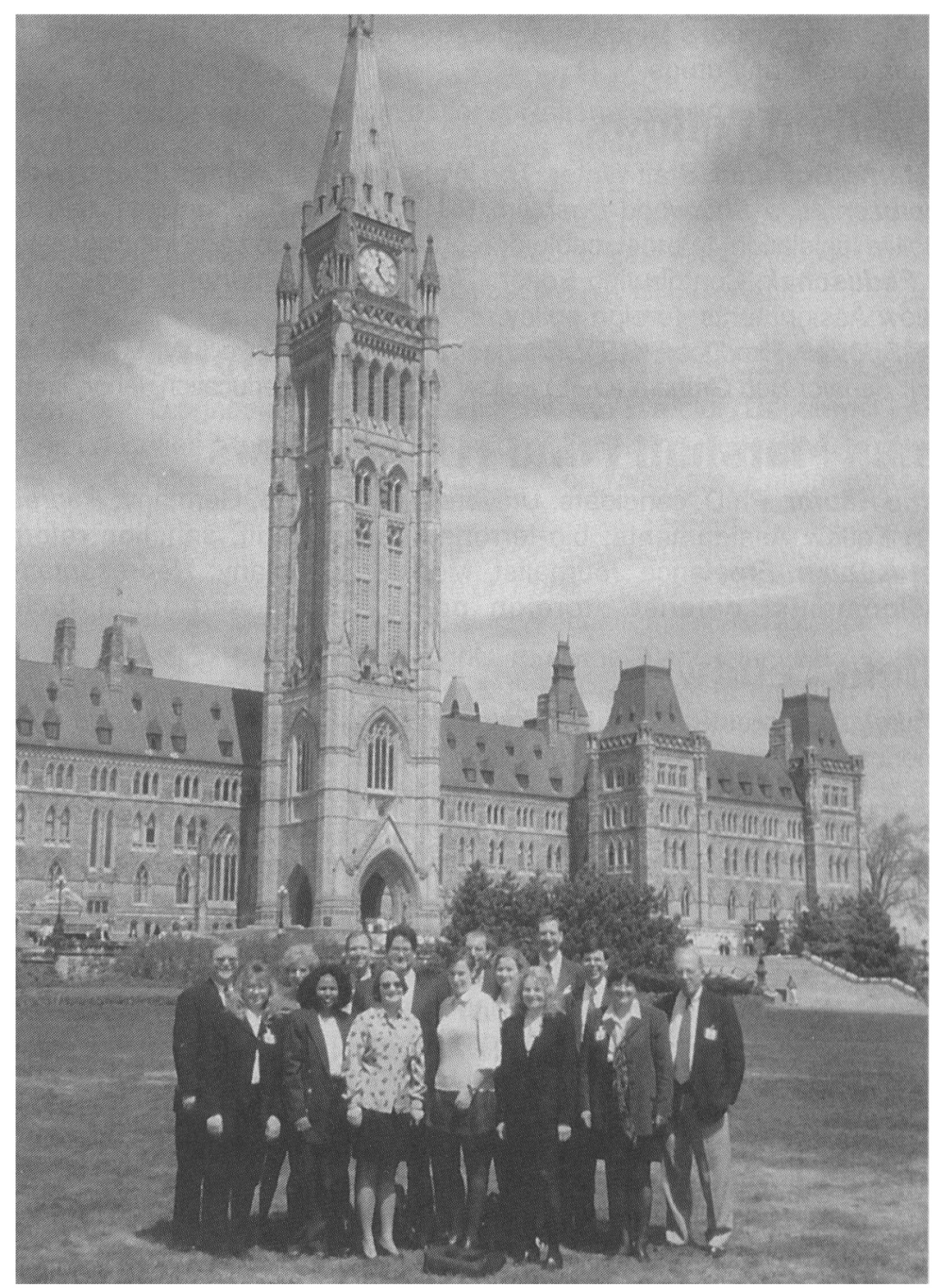

APSA Congressional Fellows participating in the annual Canadian Parliamentary Exchange gather in front of the Canadian Parliament buildings in Ottawa. Back Row (L-R): Rick Roberts, Deirdre Foley, Dan Lipinski, David Salazar, Michael Kuehlen, Art Menna, David Leal. Front Row (L-R): Donna Counterman, Patricia Jones, Susan Rzemien, Kate Kaufer, Darcia Bowman, Delia Donatelli, Natalia Feduschak, CFP Director Jeffrey Biggs. 


\section{Political Science Fellows}

David Auerswald, Assistant Professor, The George Washington University, DC; Senate Foreign Relations Committee, minority staff member on detailed by Senator Joe Biden (D-DE). Fellow Assignments: Missile defense, Arms Control, and NATO/U.S. military doctrine.

Lisa Garcia Bedolla, Ph.D. candidate, Yale University, CT; Representative Xavier Becerra (D-CA) Fellow Assignments: Hurricane Mitch/Central American relief, drug certification, banking and financial services, housing, some education/immigration/ international relations issues (primarily Latin America), D.C. special projects coordinator

Thomas Brunell, Visiting Professor, University of California, Irvine; House Govemment Reform and Oversight Committee, Subcommittee on the Census, on detail by Representative Dan Miller (R-FL) Fellow Assignments: census

Colton Campbell, Assistant Professor, Florida International University; Senator Bob Graham (D-FL) Fellow Assignments: budget and taxes.

Eric Heberlig, Ph.D. candidate, Ohio State University; Representative Tom Sawyer (D-OH) Fellow Assignments: education, labor, and environmental issues.

Benjamin Highton, Ph.D. candidate, University of California, Berkeley; Senator Paul Wellstone (D-MN) Fellow Assignments: education policy.

David Leal, Assistant Professor, State University of New York - Buffalo (Stelger Fellow); Senator John Kerry (D-MA) Fellow Assignments: social security and education.

Daniel Lipinski, Ph.D. candidate, Duke University (APSA-Mcı Congressional rellow); Democratic Policy Committee on detail by House Minority Leader, Representative Richard Gephardt(D-MO) Fellow Assignments: education, crime, and drugs.

\section{Journalism Fellows}

Darcia Harris Bowman, Staff Writer, The Watertown Daily Times (Congressional Quarterly rellow); Representative Sherwood Boehlert (R-NY) Fellow Assignments: telecommunications (overhaul of satellite legislation, Internet, cable deregulation), banking and insurance, veterans' affairs, Y2K, taxes.

Natalia Feduschak, Contributing Editor, The Ukrainian Quartenly; Senator Frank Lautenberg (D-NJ) Fellow Assignments: foreign policy.

Andrew Souvall, Producer, KUTV Channel 2 News, Salt Lake City, UT (ApsAmci Congressional rel low); Senator Bob Graham (D-FL) Fellow Assignments: education, labor, immigration, and social security.

\section{German Marshall Fund (US) Fellows}

Katherine Käufer, Ph.D. candidate, University of Cologne, Germany; Representative Bill Luther (DMN) Fellow Assignments: bio-terrorism, microcredit, sanction reform, Mercosur Study Group.

Michael Kühlen, Freelance Journalist, Münster, Germany; Representative Rush Holt (D-NJ) Fellow Assignments: defense, foreign policy (Israel and India focus), immigration, the arts.

\section{Hatfield Fellow}

Pete Wakeland, Forester, Grande Ronde, Oregon; Senator Ron Wyden (D-OR) Fellow Assignments: American Indian issues and rural land use issues.

\section{Federal Fellows}

Lora Becker, Director of Military Intelligence Staff, Defense Intelligence Agency; House Intemational Relations Committee, Asia-Pacific Subcommittee on detail by Representative Doug Bereuter (R-NE). Fellow Assignments:defense, new initiatives relative to projected outyear threats, force concepts, foreign relations (all A-P nations including NIS, Caucuses, etc.).

Donna Counterman, IT Program Manager, Agency Technology Services, Central Intelligence Agency; Representative Chris Shays (R-CT) Fellow Assignments: immigration, transportation, social security, animal rights, terrorism, government reform, part-time on Subcommittee on Terrorism issues.

Blane Dessy, Executive Director, National Library of Education, U.S. Department of Education; Representative Major Owen (D-NY) Fellow Assignments: education.

Deirdre Foley, Fair Lending Specialist, Federal Deposit Insurance Corporation; Senate Govemment Affairs Committee, minority staff; Fellow Assignments: government oversight and consumer issues.

Christine Jackson, Education Program Specialist, U.S. Department of Education ; Senator Joseph Liberman (D-CT) Fellow Assignments: education issues in preparation for reauthorization of Elementary and Secondary Education Act.

Patricia Jones, Chief, Infrastructure Planning and Strategy/Senior Computer Scientist, National Security Agency; Representative Eva Clayton (D-NC) Fellow Assignments: labor, senior issues, social security, campaign finance reform, womens' issues.

Arthur Menna, Senior Electronic Engineer, National Security Agency; Senator Mike DeWine (R-OH) Fellow Assignments: drug policy, Latin American issues including Hurricane Mitch devastation, general foreign affairs.

Carol Rest-Mincberg, Senior Management Consultant, Department of Health and Human Services; Senator Paul Wellstone (DMN) Fellow Assignments: health issues including focus on mental health and substance abuse, reauthorization of SAMHSA (the Substance Abuse and Mental Health Services Agency in HHS), mental health aspects of the patient's bill of rights and privacy/confidentiality bills. 
Stacey Rosénberg, Nuclear Engineer, Nuclear Regulatory Commission; Senator Bob Graham (D-FL) Fellow Assignments: energy, environmental, issues including children safety re. lead and mercury, coastal erosion, shore protection, environmental tax issues.

\section{Foreign Affairs Fellows}

William Adkins, Team Chief, Advanced Concepts Group, National Reconnaissance Office; Senator Spencer Abraham (R-MI) Fellow Assignments: Defense, Space, Health Care, Vets, China.

Anne Alexander, Defense Intelligence Agency; Senator Russell Feingold (D-WI) Fellow Assignments: Foreign Relations, to include specific topics such as Defense Offsets, International Bribery and Corruption, and Embassy Security.

Christopher Datta, Country Affairs Officer (Israel, Jordan, Lebanon, Syria, West Bank), U.S. Information Agency; Representative Steve Rothman (D-NJ) Fellow Assignments: international relations including Kosovo, Cuba, and Columbia earthquake.

Delia Donatelli, Deputy Division Chief, Satellite Systems Division, Department of the Air Force; Senator John Kerry (D-MA) Fellow Assignments: defense and foreign affairs.

John McNamara, Senior Watch Officer, Operations Center, Department of State; Senator Edward M. Kennedy (D-MA) Fellow Assignments: foreign relations.

Rick Roberts, Information Officer, U.S. Information Agency; Senator John Breaux (D-LA) Fellow Assignments: space, science, technology with particular emphasis on the space launch industry, foreign affairs.

Susan Rzemien, International Economist, Office of Foreign Exchange Operations, Department of Treasury;(January-April) Senator Richard Lugar (R-IN) and (May-August) House Ways and Means Committee, Subcommittee on Trade, majority staff;

Fellow Assignments: Commodity Future Trading Commission (CFTC) derivatives regulation issues, space, tax reform,

DC appropriations, international economic reform, global financial market issues.

David Salazar, Foreign Affairs Economic Analyst, Bureau of Intelligence and Research, Department of State; Senator Diane Feinstein (D-CA) Fellow Assignments; trade and general economic issues.

Joseph Stager, Chief, Administrative Branch, Office of Finance and Logistics, Central Intelligence Agency;

Representative Doug Bereuter (R-NE) Fellow Assignments: defense, technology transfer, international military exchange training.

Daniel Stewart, Vehicle Manager, Directorate of Communications, National Reconnaissance Office;

Senator Conrad Bums (R-MT) Fellow Assignments: defense, space, general science, telecommunications, immigration, judiciary, veterans' affairs, American Indian affairs.

Karen Walter, Chief, International Branch, Federal Deposit Insurance Corporation; SenatorSam Brownback (R-KS) Fellow Assignments: foreign relations related to East Asia, Europe, CenterSouth America, Africa with collateral issues including treaties, NATO, UN.

\section{Robert Wood Johnson rlealth Policy Fellows}

Robert E. Barsley, Professor, Oral Diagnosis/ Medicine/Radiology and Director, Department of Dental Health Resources Louisiana State University School of Dentistry; Senator John Breaux (D-LA) Fellow Assignments: health care issues with emphasis on Medicare, Patient Protection (ERISA), work incentives, medical record confidentiality.

David E. Fleischer, Professor of Medicine/Chief, Endoscopy Unit, Georgetown University Medical Center; Senate Labor and Human Resources Committee, Subcommittee on Public Health \& Safety on detail from Senator Bill Frist (R-TN) Fellow Assignments: Medicare Commission, graduate medical education, NIH

reauthorization, quality care initiatives including Patients' Bill of Rights, rural health and tele-medicine. Marc Hahn, Director, Pain Medicine and Palliative Care Center and Associate Professor of Anesthesia

PennState Geisinger Health System; Senate Finance Committee on detail from Senator William Roth (R-DE) Fellow Assignments: Medicare and other health issues.

Lawrence D. Kerr, Assistant Professor, Microbiology and Immunology and Cell Biology, Vanderbilt University; Senate Judiciary Committee on detail from Senator Orin Hatch (R-UT) Fellow Assignments: EST (gene sequencing patents), Radiation Exposure Compensation Act amendment (RECA, 1999), Stem cells/cloning, organ transplant, AIDS, bioterrorism, community health centers, genetic confidentiality and other privacy issues, Health Card.

Mary Beth Mazanec, Associate Professor of Medicine and Pathology, Case Western Reserve University; Senate Labor and Human Resources Committee, Subcommittee on Public Health \& Safety on detail from Senator Bill Frist (R-TN) Fellow Assignments:public health including anti-microbial resistance, genetic discrimination, medical records privacy, bio-ethical issues.

David A. Pollack, Medical Director, Mental Health Services West, Inc., Portland, OR; Senate Labor \& Human Relations Committee, Subcommittee on Public Health \& Safety on detail from Senator Edward M. Kennedy (D-MA) Fellow Assignments: health issues including focus on mental health and substance aspects such as reauthorization of SAMHSA (Substance Abuse and Mental Health Services Agency in HHS) and mental health aspects of the Patient's Bill of Rights and privacy/confidentiality legislation, early buy-in option for ages 55-64 audience.

Thomas B. Valuck, Associate Hospital Administrator/Director, Medical Staff Affairs, University of Kansas Medical Center; Senate Labor \& Human Resources Committee on detail from chairman, Senator James Jeffords (R-VT) Fellow Assignments: health care issues including patient protections, HMO reform, reauthorization of Health Care Policy and Research, rural health, children's health, public health service reauthorizations. 


\begin{tabular}{|c|c|c|}
\hline Article & Issue & Page \\
\hline \multicolumn{3}{|l|}{ American Political Science Review } \\
\hline The 1997-1998 Sail on the Flagship American Political Science Association & December 1998 & 897 \\
\hline \multicolumn{3}{|l|}{ Annual Meeting 1998} \\
\hline APSA Receives Grant from the Andrew W. Mellon Foundation (PROceedings project) & September 1998 & 678 \\
\hline 1999 Annual Meeting Call for Papers & September 1998 & 689 \\
\hline First Meeting in Boston Breaks All Records & December 1998 & 885 \\
\hline Association Hosts Honors Reception during Annual Meeting & December 1998 & 888 \\
\hline Annual Meeting Perspectives & December 1998 & 892 \\
\hline Travel Grant Programs Assist International Scholars & December 1998 & 893 \\
\hline Milner and Katznelson Named Program Co-Chairs for APSA 2000 & March 1999 & 136 \\
\hline Annual Meeting Preliminary Program & June 1999 & 325 \\
\hline \multicolumn{3}{|l|}{ Awards } \\
\hline Association Distributes Annual Awards & December 1998 & 889 \\
\hline William Anderson Award Description Adjusted & June 1999 & 305 \\
\hline \multicolumn{3}{|l|}{ Centennial Campaign } \\
\hline Beach, Miller, Prestage to Receive 1998 Goodnow Awards & September 1998 & 677 \\
\hline Centennial Campaign Update & September 1998 & 678 \\
\hline Centennial Campaign Kick-Off & December 1998 & 887 \\
\hline Centennial Campaign Supports International Scholars & December 1998 & 887 \\
\hline Kenworthy Honored in Centennial Campaign Giving & March 1999 & 139 \\
\hline \multicolumn{3}{|l|}{ Civic Education } \\
\hline $\begin{array}{l}\text { APSA Task Force on Civic Education in the 21st Century: } \\
\text { Expanded Articulation Statement }\end{array}$ & September 1998 & 636 \\
\hline \multicolumn{3}{|l|}{ Committees } \\
\hline Ad Hoc Committee on Technology Created & September 1998 & 681 \\
\hline \multicolumn{3}{|l|}{ Congressional Fellowship Program } \\
\hline Forty-Sixth Class of Congressional Fellows Named & September 1998 & 683 \\
\hline Forty-Sixth Class of Congressional Fellows Begins 1998-1999 Program & December 1998 & 917 \\
\hline $\begin{array}{l}\text { Midterm } 1998 \text { Elections, Speaker Resignation, and Impeachment } \\
\text { A Heady Atmosphere for 1998-1999 Congressional Fellows' Job Search }\end{array}$ & March 1999 & 149 \\
\hline Congressional Fellows at Work, in Seminar & June 1999 & 302 \\
\hline \multicolumn{3}{|l|}{ Council and Governance } \\
\hline Council Endorses Statement On Use of Part-Time and Adjunct Faculty & September 1998 & 679 \\
\hline Council Adopts New Guidelines for Assessing Project Proposals & September 1998 & 679 \\
\hline Student and Unemployed Membership Categories Revised & September 1998 & 679 \\
\hline APSA Council Actions & December 1998 & 894 \\
\hline APSA Guidelines on External Reviews Are Revised & December 1998 & 895 \\
\hline APSA Treasurer's Report & December 1998 & 906 \\
\hline Two Participation Rule for Annual Meeting Modified & June 1999 & 300 \\
\hline Strategic Planning Initiative Set by Council & June 1999 & 303 \\
\hline Council Holds Firm on Coursepack Permission Fees & June 1999 & 303 \\
\hline Council Makes Members Eligible for APSR Online Archive & June 1999 & 304 \\
\hline \multicolumn{3}{|l|}{ Executive Director } \\
\hline Executive Director's Report & September 1998 & 659 \\
\hline \multicolumn{3}{|l|}{ Internet } \\
\hline JSTOR Adds Mirror Site in UK; Increases American Subscriber Base & September 1998 & 681 \\
\hline APSA and ECPR Launch Online Exchange Project & December 1998 & 916 \\
\hline APSA Expands Online Services & March 1999 & 136 \\
\hline APSA Announces New Teaching Web Site & June 1999 & 297 \\
\hline \multicolumn{3}{|l|}{ Organized Sections } \\
\hline Section News & December 1998 & 921 \\
\hline Section News & March 1999 & 154 \\
\hline \multicolumn{3}{|l|}{ Presidents and Officers } \\
\hline Matthew Holden Jr.: Between Theory and Practice & September 1998 & 653 \\
\hline New APSA Officers and Council Elected & December 1998 & 894 \\
\hline Association Officers and Council Members Nominated for $1999-2000$ & June 1999 & 285 \\
\hline Holden Submits New Appointments; Announces Sabbatical for Rudder & June 1999 & 301 \\
\hline \multicolumn{3}{|l|}{ Profession and Professional Development } \\
\hline $\begin{array}{l}\text { A Postscript to "Finding Jobs in Political Science": A Survey of 1996-1997 } \\
\text { Ph.D.'s Employment Searches and Outcomes }\end{array}$ & March 1999 & 141 \\
\hline PS Reports & & \\
\hline Index of APSA Reports in PS & September 1998 & 685 \\
\hline Research Support & & \\
\hline APSA Names Research Grant Winners & September 1998 & 679 \\
\hline Women and Minorities & & \\
\hline Encouraging the Brightest: 1998 Ralph Bunche Summer Institute & September 1998 & 681 \\
\hline Spring Round of Minority Identification Project a Big Success & September 1998 & 682 \\
\hline 1998-1999 Minority Fellows Choose Graduate Schools & September 1998 & 683 \\
\hline Survey of APSA Minority Identification Project Students & December 1998 & 914 \\
\hline 1999-2000 APSA Minority Fellows Named & March 1999 & 148 \\
\hline 1998 Fall Round of Minority Identification Project Sets Records & March 1999 & 148 \\
\hline 1999 Ralph Bunche Summer Institute Participants Selected & June 1999 & 305 \\
\hline
\end{tabular}

no doubt aware (if not, you certainly will be after this week), the Can-Am relationship is one of the most unique and important bilateral relationships in the world. We hope that you will come away from your week in Ottawa with a new appreciation for this relationship and the politics that are practiced above the 49th."

To assist them in pounding that point home, the parliamentary interns tapped into the upper echelons of their political system. We didn't meet with any of the "assistant to the assistant" types that are forever proliferating in our own federal system. The Canadians offered us nothing short of their top officials, their best and brightest, their most revered. On the first day alone, we heard from and asked questions of two members of Parliament and a Supreme Court justice. Prime Minister Jean Chretien, a former prime minister, the speaker of the House of Commons, and arguably the country's highest profile journalist, Jeffrey Simpson of The Globe and Mail, are just a few of. those who followed. We were treated to a dinner discussion with Government House Leader Don Boudria about "Party Discipline in the Canadian Parliament," and some of us also had the opportunity to further discuss issues of national unity versus sovereignty over dinner and drinks with the foreign affairs critic for the Bloq Quebecois in Parliament, Daniel Turp.

But it was the Honourable Mitchell Sharp, former minister of finance and foreign affairs in the Pearson and Trudeau governments, who most clearly stated the idea I suspect all of the Canadians were delicately trying to convey to their American guests. "It is not for me to say whether your system is good for you. It is yours. It is the one you have chosen. And our system, though different from yours, is the one we have chosen and it is right for us." For those of us who believed Canada would be better off, and have fewer of the sort of problems it is experiencing with respect to Quebec, if it was part of or more like the United States, this is the lesson: Canada and the U.S. are inextricably linked geographically and economically, but we are different- 


\section{Washington Insider}

\section{Copyright Office Issues Report on Distance Education and Copyright Law}

As mandated in 1998's Digital Millennium Copyright Act (H.R. 2281), the U.S. Copyright Office has issued "Copyright and Digital Distance Education" (www. loc.gov/copyright/disted/). The 348-page report surveys the practical and legal issues about distance education and concludes with a consideration of whether copyright law should be changed to permit best instructional use of digital technologies. Basing its conclusions on extensive research, comments received during hearings, and input from members of affected groups, the report's authors concluded copyright law should be modified to expand performance exceptions for educational uses of copyrighted materials and include safeguards to minimize risks of uncontrolled digital copying and distribution. The report also calls for preparation of a judicial history of "fair use" and an affirmation that the right is "technology neutral."

\section{Little Good News Concerning Federal Declassification Efforts}

May was generally a bad month for declassification. On May 11, Secretary of Energy Bill Richardson announced that his agency would not be able to meet an April 2000 deadline for declassification of all but its most sensitive records over 25 years old. Executive Order 12958 gives federal agencies five years, beginning in 1995, to review and release or reclassify its old records. Richardson claimed Energy needed an additional 18 months and may reconceive its declassification program following the discovery of major security breaches involving computer records at Los Alamos National Laboratory. On May 24, the House Armed Services Committee voted out an authorization bill containing a $\$ 20$ million cap for Defense Department declassification activities. Defense estimates it spends $\$ 200$ million a year on declassification. The defense appropriation bill approved in the Senate does not contain a cap, but does have language introduced by Trent Lott (R-MS) calling for page-by-page reviews of most of the hundreds of thousands of documents already released pursuant to E.O. 12958. A solitary piece of good news came from the State Department, which announced that it will complete its classification review by April 2000. To date, State has released about $97 \%$ of the nearly 49 million pages it has reviewed.

\section{Faculty at Ohio State Schools Denied Right to Negotiate Workload}

Pending further U.S. Supreme Court review of a 1993 Ohio law requiring "the Ohio board of regents jointly with all state universities ... [ [to] develop standards for instructional workloads," faculty at state-funded universities in Ohio will no longer be able to collectively negotiate their workloads. The Ohio State Supreme Court struck down the law because a section placing workloads off-limits for collective bargain was found to violate faculty members' right to equal protection (83 Ohio St. 3d 229, 699 N. E. 2d 463; 1998). In short, the Ohio court found that the state had no compelling reason to deny faculty a right enjoyed by most Ohio state employees. In granting a writ of certiorari in Central State University v. American Association of University Professors, Central State University Chapter (98-1071), the Supreme Court overturned the earlier decision and agreed to issue its own ruling regarding whether the Ohio legislature was justified in restricting faculty's collective bargain rights in order to achieve the publicly desirable end of having professors spend more time teaching. No evidence produced during previous cases has shown a link between collective bargaining and decreased instructional time.

\section{People on the Move}

Craig Calhoun, chair of the sociology department at New York University and editor of the journal Sociological Theory, has been named the new president of the Social Science Research Council. A. Lee Fritschler, president of Dickinson College, has been appointed assistant secretary for postsecondary education in the U.S. Department of Education. historically, politically, culturallyand we would be remiss to discount those differences.

APSA Congressional Fellows are given a rare opportunity each year to fully explore and, I think, to appreciate these differences between the United States and Canada. Time has proven there is an undeniable value to allowing young journalists working for newspapers and television stations outside of Washington, political scientists who often return to teaching jobs at colleges across the country, and other professionals on both sides of the beltway to gain an insider's understanding of the congressional process. It only stands to reason these same individuals are better off for participating in a comparative study of two widely replicated models for governing, and for taking the time to view the United States from the perspective of a neighbor of whom it has enjoyed the dubious privilege of taking for granted. 